\title{
OPTIMALISASI KINERJA PEMERINTAHAN DESA DALAM PENYUSUNAN RENCANA KERJA PEMBANGUNAN DESA
}

\author{
Rudiadi, Abdiana Ilosa, Saipul Al Sukri \\ Universitas Islam Negeri Sultan Syarif Kasim Riau \\ Email: rudiadi.r@uin-suska-ac.id
}

\begin{abstract}
This research is a qualitative research by prioritizing an empirical juridical approach. The empirical juridical approach is intended to analyze problems by combining materials in the form of secondary data with primary data obtained in the field, namely the implementation of the preparation of village government work plans which are jointly determined annually between the Village Government and BPD as community representatives. This research was conducted in Sekeladi Village, Tanah Putih District, Rokan Hilir Regency, Riau. The types and sources of data used in this study were divided into primary data (interviews, observations), and secondary data obtained from library materials. All data that has been collected by researchers is analyzed based on performance standards according to Sumoroto, namely efficiency, effectiveness, fairness, and responsiveness. Based on the results of the analysis related to the problems above, the researchers concluded that the performance of the Sekeladi Village government in discussing and compiling village government work plans so far has not been carried out properly, it is influenced by several factors, namely the lack of cooperation between village government institutions, there are still work programs that are not on target, the village government is less responsive in absorbing the aspirations and desires of the village community.
\end{abstract}

Keywords: Performance, The Village Government, Village Development

\begin{abstract}
Abstrak
Penelitian ini merupakan penelitian kualitatif dengan mengedepankan pendekatan yuridis empiris. Pendekatan yuridis empiris dimasksudkan untuk menganalisis permasalahan dengan memadukan bahan-bahan berupa data sekunder dengan data primer yang diperoleh dilapangan yaitu tentang pelaksanaan Penyusunan rencana kerja pemerintahan desa yang setiap tahun ditetapkan bersama antara Pemerintahan Desa dan BPD sebagai perwakian masyarakat. Penelitian ini dilakukan di Desa Sekeladi Kecamatan Tanah Putih, Kabupaten Rokan Hilir, Riau. Jenis dan sumber data yang digunakan dalam penelitian ini dibagi dalam data primer (wawancara, observasi), serta data sekunder yang diperoleh dari dari bahan kepustakaan. Semua data yang telah dikumpulkan oleh peneliti dilakukan proses analisis berdasarkan standard kinerja menurut Sumoroto yaitu Efisiensi, efektifitas, keadilan, serta daya tanggap. Berdasarkan hasil analisis terkait masalah diatas, maka peneliti memperoleh kesimpulan bahwa kinerja pemerintahan Desa Sekeladi dalam membahas dan menyusun rencana kerja pemerintahan desa selama ini belum terlaksana dengan baik, hal itu dipengaruhi oleh beberapa faktor, yaitu kurangnya kerjasama antar lembaga pemerintahan desa, masih adanya program kerja yang tidak tepat sasaran, kurang tanggapnya pemerintahan desa dalam menyerap aspirasi dan keinginan masyarakat desa.
\end{abstract}

Kata Kunci: Kinerja, Pemerintahan Desa. Pembangunan Desa. 


\section{PENDAHULUAN}

Sejarah perjalanan pemerintahan Indonesia telah banyak mengalami perubahan terutama dalam aspek ketatanegaraan. Berakhirnya kekuasaan orde baru menandakan bahwa negara ini telah memasuki era reformasi yang kemudian semakin memperjelas sistem otonomi daerah. Namun begitu, tarik ulur hubungan antara pusat dan daerah dalam keragka otonomi daerah ini dari dulu hingga sekarang masih belum menemukan format ideal, bahkan cenderung terjadinya ketegangan yang tak berkesudahan (Ni'matul Huda, 2013:77).

Otonomi daerah di Indonesia merupakan hal yang menarik untuk diamati dan dikaji, karena semenjak para pendiri negara menyusun format negara, isu menyangkut pemerintahan lokal telah diakomodir dalam Pasal 18 UUD 1945 bahwa negara mengakui adanya keberagaman dan hak asal usul yang merupakan bagian dari sejarah panjang bangsa Indonesia (J. Kaloh, 2007;1). Salah satu penguatan terhadap kebijakan otonomi daerah tersebut kemudian lahir UU Nomor 22 Tahun 1999 Tentang Pemerintahan Daerah, yang kemudian diganti dengan UU Nomor 32 Tahun 2014, serta UU Nomor 23 Tahun 2014 Tentang Pemerintahan Daerah.

Otonomi daerah sejatinya tidak berakhir pada wilayah provinsi dan kabupaten saja, namun semangat tersebut harus sampai pada wilayah terkecil yaitu desa. Menurut Romli dan Nurlita (2017) pemerintahan desa adalah unit terkecil dalam pelayanan kepada masyarakat sekaligus sebagai peran strategis dalam keberhasilan program pemerintah. Hal senada juga disampaikan (Ilosa et al, 2021) bahwa desa merupakan ujung tombak dalam pencapaian keberhasilan program pembangunan nasional. Lahirnya UU Nomor 6 Tahun 2014 menjadi angin segar bagi masa depan pembangunan desa. Pembangunan desa dapat mendorong kesejahteraan dan pengurangan angka kemiskinan (Budiono, 2015). Kesadaran itu itu harus ada mengingat Sebagian penduduk miskin berada di wiliyah pedesaan (Al Sukri et al, 2020). Sebagai bentuk keseriusan pemerintah dalam membangun kawasan pedesaan lahirlah Peraturan Menteri Dalam Negeri (Permendagri) Nomor 114 Tahun 2014 Tentang Pedoman Pembangunan Desa (Didik Soeharto, 2016:25).

Berlakunya UU Desa dan Permendagri Nomor 114 Tahun 2014 Tentang Pedoman Pembangunan Desa, membawa berbagai implikasi terhadap rencana pembangunan yang ada di desa, antara lain: 
a. Desa / sebutan lain wajib menyusun Rencanaan Pembangunan Desa Yakni: (1) Rencanaan Pembangunan Jangka Menengah (RPJM) Desa dengan jangka waktu enam tahun; (2) Rencana Kerja Pemerintah (RKP Desa) sebagai penjabaran dari RPJMD dengan jangka waktu satu (1) tahun.

b. RPJMD maupun RKP Desa yang disusun harus mengacu pada Perencanaan Pembangunan Kota / Kabupaten.

c. Penyusunan Perencanaan Pembangunan Desa wajib menyertakan atau melibatkan masyarakat melalui kegiatan yang dikenal sebagai Musyawarah Rencana Pembangunan Desa (Musrenbangdes);

d. Perencanaan Pembangunan Desa harus didasarkan pada kebutuhan masyarakat desa sebagaimana ditetapkan pada UU Nomor 6 Tahun 2014 serta Permendagri Nomor 114 Tentang Pedoman Pembangunan Desa;

e. Orientasi Pembangunan Desa sebagaimana ditetapkan pada Pasal 78. Undangundang No 6 tahun 2014 yakni : Meningkatkan kesejahteraan masyarakat desa, meningkatkan kualitas hidup, penanggulangan kemiskinan, pembangunan sarana dan prasarana desa, pengembangan ekonomi lokal, serta pemanfaatan sumberdaya alam dan lingkungan secara berkelanjutan.

Keberhasilan pembangunan desa bukan hanya terletak pada kemampuan pemerintahan desa saja, tetapi juga berkaitan dengan sejauh mana partisipasi masyarakat dalam menjalankan program pembangunan. Menurut Ndraha (dalam Huraerah, 2011:110) partisipasi masyarakat dalam pembangunan sangat diperlukan mulai dari tahap perencanaan, tahap pelaksanaan, tahap pemanfaatan, serta tahap evaluasi. Oleh karena itu, partisipasi masyarakat serta elemen pemerintahan desa merupakan hal penting dilakukan termasuk dalam proses penyusunan RKP Desa.

Berlakunya UU Desa serta Permendagri Nomor 114 Tahun 2014 menjadi kewajiban bagi pemerintahan desa, tidak terkecuali di Desa Sekeladi. Desa Sekeladi merupakan salah satu desa yang terletak di Kec. Tanah Putih, Kab. Rokan Hilir. Secara Demografis, Desa Sekeladi merupakan desa atau kepenghuluan yang terletak di pinggiran aliran Sungai Rokan yang membentang dari daerah Rokan Hulu dan bermuara di laut Bagan Kota Bagan Siapiapi. Oleh karena itu, dalam menjalankan program pemerintahan yang berbasis pada kesejahteraan masyarakat desa, sudah sepatutnya pemerintah Desa Sekeladi dalam menyusun RKP Desa mempertimbangkan 
kondisi desa dan kebutuhan mendasar masyarakat Desa Sekeladi, hal ini mengingat tujuan dari kebijakan undang-undang tentang desa dalam hal Rencana Pembangunan Desa adalah demi kemajuan masyarakat desa.

Berkaitan dengan proses penyusunan RKP Desa, maka dalam Permendagri Nomor 144 dijelaskan, yakni:

a. Pasal 2 ayat (1) Pemerintah desa menyusun perencanaan pembangunan desa sesuai dengan kewenangannya dengan mengacu pada perencanaan pembangunan Kabupaten/Kota. (2) Pembangunan desa sebagaimana dimaksud pada ayat (1) dilaksanakan oleh pemerintahan desa dengan melibatkan seluruh masyarakat desa dengan semangat gotong royong.

b. Pasal 3: Pembangunan desa Sebagaimana dimaksud dalam Pasal 2 mencakup bidang penyelenggaraan pemerintahan desa, pelaksanaan pembangunan desa, pembinaan dan pemberdayaan masyarakat desa.

Mengacu dari apa yang dijelaskan dalam Permendagri diatas maka dapat diambil kesimpulan bahwa untuk melaksanakan pembangunan di desa maka pemerintahan desa harus mengacu pada perencanaan pembangunan kabupaten/kota, dengan melibatkan seluruh masyarakat desa secara gotong royong. Selain itu, dalam Permendagri tersebut juga dijelaskan bahwa program perencanaan pembangunan desa harus melingkupi semua aspek, seperti pelaksanaan pembangunan desa, pembinaan kemasyarakatan dan pemberdayaan masyarakat desa.

Terkait RKP Desa Sekeladi tahun 2019 yang dibahas dalam Musyawarah Rencana Pembangunan Desa (Musrenbangdes) pada pertengahan bulan September tahun 2018 dan disahkan pada Tanggal 19 Februari tahun 2019 dalam Peraturan Kepenghuluan (PERKEP) Nomor 5 Tahun 2019 Tentang Anggaran Pendapatan dan Belanja Kepenghuluan 2019. Dibawah ini dijelaskan Data Jumlah Anggaran Pendapatan dan Belanja Desa (APB Desa) Kepenghuluan Sekeladi pada tahun 20192020, sebagai berikut:

Tabel 1: Anggaran Pendapatan dan Belanja Kepenghuluan Sekeladi 2019

\begin{tabular}{ccc}
\hline NO & $\begin{array}{c}\text { Jumlah Anggaran Pendapatan Belanja } \\
\text { Kepenghuluan (APBKep) Sekeladi 2019 }\end{array}$ & $\begin{array}{c}\text { Total Jumlah Anggaran Belanja } \\
\text { Desa Sekeladi }\end{array}$ \\
\hline 1 & Jumlah: Rp. 2.171 .416 .546 .00 & Jumlah: Rp. 2.665 .281 .350 .00 \\
& & \\
\hline
\end{tabular}

Sumber: Peraturan Kepenghuluan Sekeladi Tentang APB Desa Sekeladi 2019 
Dalam perjalanannya, pembahasan Musrenbang tersebut dihadiri oleh Kepala Desa, Sekretaris Desa, Kaur Pemerintahan. Selain itu, Musrenbang tersebut juga dihadiri oleh 16 orang RT dari 22 RT yang ada, serta beberapa orang tokoh masyarakat Desa Sekeladi. Berikut dijelaskan data rencana kegiatan pembangunan Desa Sekeladi yang telah di laksanakan pada tahun 2019-2020.

Tabel 2: Tabel Program RKP Desa Sekeladi 2019

\begin{tabular}{|c|c|c|c|c|}
\hline NO & $\begin{array}{c}\text { URAIAN } \\
\text { PEKERJAAN }\end{array}$ & DANA & $\begin{array}{c}\text { KODE } \\
\text { KEGIATAN }\end{array}$ & $\begin{array}{l}\text { KODE } \\
\text { REK }\end{array}$ \\
\hline \multirow[t]{2}{*}{$\mathbf{I}$} & Sub Bidang Pek. Umum dan Penataan Ruang & & 02.03 & \\
\hline & Pembuatan Jalan Kep. Sekeladi Ruas 1 & ADD 2019 & 02.03 .05 & 5.3 .5 \\
\hline \multirow[t]{2}{*}{ II } & Sub Bidang Pek. Umum dan Penataan Ruang & & 02.03 & \\
\hline & $\begin{array}{l}\text { Lanjutan Semenisasi Jl. Kh. Anwar Dusun } \\
\text { Menggala VI }\end{array}$ & ADD 2019 & 02.03 .11 & 5.3 .5 \\
\hline \multirow[t]{2}{*}{ III } & Sub Bidang Pek. Umum dan Penataan Ruang & & 02.03 & \\
\hline & $\begin{array}{l}\text { Lanjuta Pekerjaan Sirtu Jl. Sidoarjo Dusun } \\
\text { Sukajadi }\end{array}$ & ADD 2019 & 02.03 .10 & 5.3 .5 \\
\hline \multirow[t]{2}{*}{ VI } & Sub Bidang Pek. Umum dan Penataan Ruang & & 02.03 & \\
\hline & Pembangunan Semenisasi Jl. Kh. Muda & ADD 2019 & 02.03 .12 & 5.3 .5 \\
\hline \multirow[t]{2}{*}{ VII } & Sub Bidang Pek. Umum dan Penataan Ruang & & 02.03 & \\
\hline & $\begin{array}{l}\text { Pembangunan Box Culvert Jl. Pemda } \\
\text { Pembangunan Dinding Turap Sungai Rokan }\end{array}$ & ADD 2019 & $\begin{array}{l}02.03 .11 \\
02.03 .11\end{array}$ & 5.3 .5 \\
\hline \multirow[t]{2}{*}{ VIII } & Sub Bidang Pek. Umum dan Penataan Ruang & & 02.03 & \\
\hline & $\begin{array}{l}\text { Pembangunan Semenisasi Jl. Bagan Topah } \\
\text { Dusun Menggala VI }\end{array}$ & ADD 2019 & 02.03 .14 & 5.3 .5 \\
\hline \multirow[t]{2}{*}{ IX } & Sub Bidang Pek. Umum dan Penataan Ruang & & 02.03 & \\
\hline & $\begin{array}{l}\text { Pembangunan } 3 \text { Unit Gorong-gorong Jl. Sidoarjo } \\
\text { Dusun Sukajadi }\end{array}$ & ADD 2019 & 02.03 .14 & 5.3 .5 \\
\hline \multirow[t]{2}{*}{$\mathbf{X}$} & Sub Bidang Pek. Umum dan Penataan Ruang & & 02.03 & \\
\hline & Lanjutan Galian Grainase Kep. Sekeladi Ruas II & ADD 2019 & 02.03 .10 & 5.3 .5 \\
\hline
\end{tabular}

Sumber: Kantor Kepala Desa Sekeladi Tahun 2019

Berdasarkan tabel diatas, secara umum dapat diambil kesimpulan bahwasanya pelaksaanaan rencana pembangunan desa sekeladi pada tahun pembangunan 2019 hingga 2020 secara umum hanya terfokus pada pembangunan jalan baru, semenisasi dan pembuatan gorong-gorong jalan desa. (Lihat: Data RKP Desa Sekeladi 2019).

Pada saat Peneliti melakukan kegiatan observasi, Peneliti menemukan adanya indikasi bahwa Rencana Kegiatan Pembangunan di Desa Sekeladi terkesan lamban, dan adanya indikasi bahwa penyusunan rencana pembangunan desa tanpa melibatkan masyarakat desa secara langsung, sementara dijelaskan di dalam undang-undang Nomor 6 Tahun 2014 serta Permendagri Nomor 114 Tahun 2014 yang mewajibkan adanya partisipasi dari masyarakat terkait penyusunan rencana pembangunan. Selain itu fenomena lain yang jadi permasalahan yaitu Kepala Desa dalam penyusun rencana 
pembangunan desa terindikasi dilakukan tanpa adanya kajian mendalam sehingga belum mampu menjadi solusi pengentasan kemiskinan serta memberikan kesejahteraan masyarakat. Sejalan dengan ini, Yohanes (2018) mengatakan tolak ukur dari keberhasilan pemerintahan desa dalam pembangunan dapat dilihat dari keberhasilan pembangunan desa.

Disisi lain, dari jumlah anggaran yang ada, baik yang bersumber dari Kabupaten/Provinsi (Alokasi Dana Desa) maupun dana dari APBN (Dana Desa) yang jumlah bisa mencapai 2 milyar pertahun (lihat: perkep sekeladi no.5 tahun 2019), namun besarnya jumlah dana tersebut tidak berbanding lurus dengan pembangunan di Desa Sekeladi dalam beberapa tahun terakhir. Dari pemaparan latar belakang masalah yang telah dijabarkan diatas, penulis menemukan gambaran masalah tentang optimalisasi kinerja pemerintahan desa dalam penyusunan RKP Desa. Oleh karena itu, judul yang diangkat dalam penelitian ini adalah analisis tentang kinerja pemerintahan desa dalam penyusunan RKP Desa.

\section{TELAAH LITERATUR}

\section{a. Konsep Kinerja}

Dalam Kamus Besar Bahasa Indonesia (KBBI) dijelaskan bahwa kinerja adalah sesuatu yang dicapai, prestasi yang diperlihatkan, dan kemampuan kerja. Dari pengertian diatas bahwa kinerja merupakan kemampuan seseorang dalam melaksanakan pekerjaannya serta hasil pekerjaannya. Menurut Mangkunegara (dalam Harbani Pasolong, 2007:67), mengatakan bahwa kinerja adalah merupakan hasil kerja secara kualitas dan kuantitas yang dicapai oleh seseorang dalam melaksanakan fungsinya sesuai dengan tanggungjawab yang diberikan kepadanya.

Selanjutnya, Mangkunegara (2001:67), mengatakan bahwa kinerja merupakan istilah yang berasal dari kata Job performance atau Actual performance (prestasi kerja atau prestasi sesungguhnya yang dicapai oleh seseorang). Pengertian kinerja (prestasi kerja) adalah hasil kerja secara kualitas dan kuantitas yang di capai oleh seseorang pegawai dalam melaksanakan tugasnya sesuai dengan tanggung jawab yang di berikan kepadanya.

Dari berbagai definisi diatas, dapat disimpulkan bahwa kinerja mempunyai beberapa unsur yaitu: (1) Hasil kerja dicapai secara individual atau secara institusi, yang berarti kinerja tersebut adalah hasil akhir yang diperoleh secara sendiri-sendiri 
atau kelompok; (2) Dalam melaksanakan tugas, orang atau lembaga diberikan wewenang dan tanggungjawab, yang berarti orang atau lembaga tentu saja harus mengikuti aturan yang lebih baik; (3) Pekerjaan haruslah dilakukan secara legal, yang berarti dalam melaksanakan tugas individu atau lembaga tentu saja harus mengikuti aturan yang telah ditetapkan; (4) Pekerjaan tidaklah bertentangan dengan moral atau etika, artinya selain mengikuti aturan yang telah ditetapkan, tentu saja pekerjaan tersebut haruslah sesuai moral dan etika yang berlaku umum.

Selanjutnya, berhasil atau tidaknya suatu kinerja maka sangat dipengaruhi oleh faktor-faktor tertentu. Untuk mengetahui faktor yang mempengaruhi (determinan) kinerja personel, dilakukan pengkajian terhadap beberapa teori kinerja. Selain itu, ada beberapa hal yang mempengaruhi perilaku kerja dan kinerja yaitu: variabel individu, variabel organisasi dan variabel psikologis. Ketiga kelompok variabel tersebut mempengaruhi perilaku kerja yang pada akhirnya berpengaruh pada kinerja personel.

Selanjutnya, Kumoroto (2005: 76) menggunakan beberapa kriteria untuk dijadikan pedoman dalam menilai kinerja organisasi pelayanan publik, yaitu:

a. Efisiensi, yaitu menyangkut tentang keberhasilan organisasi pelayanan public untuk memperoleh keuntungan, memanfaatkan faktor-faktor produksi serta pertimbangan yang berasal dari rasionalitas ekonomis.

b. Efektivitas, yaitu berkaitan dengan rasionalitas teknis, nilai, misi, tujuan organisasi serta fungsi agen pembangunan.

c. Keadilan, keadilan mempertanyakan distribusi dan alokasi layanan yang diselenggarakan oleh organisasi pelayanan publik.

d. Daya Tanggap, yaitu mengindikasikan tentang sejauh mana organisasi atau pelayanan publik dalam menanggapi kebutuhan dasar masyarakat.

Oleh karena itu, berhasil atau tidaknya suatu kinerja selain dipengaruhi sebab dan factor-faktor tertentu, seperti yang dijelaskan Sumoroto diatas yaitu efisiensi, efektifitas, keadilan serta daya tangganp.

\section{b. Konsep Pemerintahan Desa}

Berkaitan tentang pemerintahan desa yaitu dalam Pasal 1 ayat 3 Undang-undang Nomor 6 Tahun 2014 dijelaskan bahwa: Pemerintahan desa adalah penyelenggaraan urusan pemerintahan dan kepentingan masyarakat setempat dalam sistem pemerintahan Negara Kesatuan Republik Indonesia. 
Selain itu, menurut Adon Nasrullah jamaludin (2015;110) pemerintah desa merupakan bagian dari pemerintah nasional, yang penyelenggaraannya ditujukan kepada desa. Pemerintah desa dan Badan Permusyawaratan Desa (BPD) bertanggungjawab dalam mengatur dan menguru kepentingan masyarakat setempat berdasarkan asal-usul dan adat istiadat setempat yang diakui dan dihormati dalam system Negara Indonesia.

Selanjutnya, dalam UU Nomor 6 Tahun 2014 dijelaskan bahwa Pemerintah desa adalah Kepala Desa atau yang disebut dengan nama lain dibantu peragkat desa sebagai unsur penyelenggara pemerintahan desa. Kewenangan desa berdasarkan PP No. 72 Tahun 2005 tentang desa dijelaskan bahwa desa mempunyai tugas pokok (Adon Nasrullah, 2015;120), yaitu: a) Urusan pemerintahan yang sudah ada berdasarkan hak asal usul desa; b) Melaksanakan urusan rumah tangga desa, urusan pemerintahan umum, pembangunan dan pembinaan masyarakat; c) Menjalankan tugas pembantuan dari pemerintah, pemerintah provinsi, dan pemerintah kabupaten; d) Urusan pemerintahan lainnya yang oleh peraturan perundangan diserahkan kepada desa.

Sedangkan organisasi pemerintahan desa terdiri dari: a) Unsur pemimpin, yaitu Kepala desa; b) Unsur pembantu Kepala desa, yang terdiri dari: Sekretaris desa, yaitu unsur staf atau pelayanan yang diketuai oleh sekretaris desa, Unsur Pelaksana teknis, yaitu unsur pembantu kepala desa yang melaksanakan urusan teknis di lapangan seperti urusan pengairan, keagamaan, dan lain-lain, Unsur kewilayahan, yaitu pembantu kepala desa di wilayah kerjanya seperti kepla dusun.

\section{c. Konsep Perencanaan Pembangunan Desa}

Menurut Raharjo Adisasmita (dalam Adon Nasrullah,2015;219) pembangunan merupakan suatu proses yang berdimensi jamak (multidimensional), mencakup perubahan orientasi dan organisasi dari system sosial, ekonomi, politik, dan budaya. Sedangkan Menurut Rogers (dalam Rochajat, dkk: 2011:3) pembangunan adalah perubahan yang berguna menuju sustu sistem sosial dan ekonomi yang diputuskan sebagai kehendak suatu bangsa.

Pembangunan desa adalah upaya peningkatan kualitas hidup dan kehidupan untuk sebesar-besarnya kesejahteraan masyarakat desa. Menurut Wahjudin (2015:266267) Pembangunan desa tidak terlepas dari konteks manajemen pembangunan daerah baik di tingkat kabupaten maupun tingkat provinsi karena kedudukan desa dalam 
konteks yang lebih luas (sosial, ekonomi, akses pasar, dan ploitik) harus melihat keterkaitan antar desa, desa dalam kecamatan, antarkecamatan dan kabupaten dan antar kabupaten.

Selanjutnya, Membuat perencanaan dalam pembangunan sebuah desa menjadi mandiri ini adalah hal yang sangat penting dilakukan oleh pemerintahan desa. Untuk mewujudkan perencanaan pembangunan pedesaan, menurut Adon Nasrullah (2015; 240) ada beberapa langkah yang perlu dilakukan yaitu: 1) Mengembangkan dan meningkatkan usaha masyarkat secara terpadu di segala bidang; 2) Melaksanakan pelaksanaan usaha keluarga berencana; 3) Meneliti potensi wilayah masring-asing; 4) Meningkatkan kualitas sumber daya masyarakat melalui penyuluhan; 5) Meningkatkan usaha penerangan di pedesaan; 6) Meningkatkan dan memelihara sarana prasrana yang telah ada; 7) Melakukan program padat karya; 8) Melaksanakan usaha pada perbaikan dan pelestarian lingkungan.

\section{METODE PENELITIAN}

Penelitian ini merupakan penelitian kualitatif dengan mengedepankan pendekatan yuridis empiris. Pendekatan yuridis empiris dimasksudkan untuk menganalisis permasalahan dengan memadukan bahan-bahan berupa data sekunder dengan data primer yang diperoleh dilapangan yaitu tentang pelaksanaan Penyusunan rencana kerja pemerintahan desa yang setiap tahun ditetapkan bersama antara Pemerintahan Desa dan BPD sebagai perwakian masyarakat. Lokasi Penelitian ini dilakukan di Desa Sekeladi Kecamatan Tanah Putih, Kabupaten Rokan Hilir, Riau. Adapun alasan utama melaksanakan penelitian ini dikarenakan Peneliti menilai adanya indikasi kurang maksimalnya kinerja Pemerintahan Desa Sekeladi dalam penyusunan rencana kerja pemerintahan desa tahun 2019.

Jenis dan sumber data yang digunakan dalam penelitian ini dibagi dalam data primer (wawancara, observasi), serta data sekunder yang diperoleh dari dari bahan kepustakaan. Selanjutnya, adapun teknik Penarikan Informan dalam Penelitian ini menggunakan teknik Purpossive Sampling, dengan membagi informan dalam tiga bagian yaitu informan kunci (Kepala Desa), informan utama (Ketua BPD dan Kaur Pembangunan) serta informan tambahan. Semua data yang telah dikumpulkan oleh peneliti akan dilakukan proses analisis berdasarkan standard kinerja menurut Sumoroto yaitu Efisiensi, efektifitas, keadilan, serta daya tanggap. 


\section{HASIL DAN PEMBAHASAN}

\section{A. Peran Pemerintahan Desa Sekeladi dalam penyusunan RKP Desa}

Berlakunya UU Nomor 6 Tahun 2014 Tentang Desa seakan memberi ketegasan bahwa sejatinya pemberian system otonomi dan hak mengatur pemerintahan dan pembangunan tidak hanya pada tataran Pemerintahan Daerah saja, namun juga diberikan kewenangan pada pemerintahan desa untuk melaksanakan pembangunan yang ada di desa sesuai dengan hak asal usul desa tersebut. Selain itu, lahirnya UU No.6 Tahun 2014 diharapkan mampu menciptakan percepatan pembangunan berskala local yang akan mempercepat pertumbuhan pembangunan ekonomi daerah yang tersebar diseluruh desa (Soimin, 2019:2).

Selanjutnya, di dalam UU Nomor 6 Tahun 2014 dijelaskan bahwa pembangunan desa bertujuan meningkatkan kesejahteraan masyarakat desa dan kualitas hidup manusia serta penanggulangan kemiskinan melalui pemenuhan kebutuhan dasar, pembangunan sarana dan prasarana desa, pengembangan potensi ekonomi lokal, serta pemanfaatan sumber daya alam dan lingkungan secara berkelanjutan (Lihat: UU No.6 Tahun 2014). Oleh karena itu, untuk memastikan pembangunan wilayah desa yang berkelanjutan, maka pemerintahan desa berdasarkan ketentuan yang ada dalam UU Desa juga harus melakukan menyusun Rencana Pembangunan Jangka Menengah (RPJMDes) untuk masa kerja 6 tahun, dan RKP Desa untuk masa kerja 1 tahun.

Penyelenggaraan pemerintahan desa hakikatnya dilaksanakan oleh Pemerintah Desa dan Badan Permusyawaratan Desa, pemerintah desa merupakan organisasi pemerintahan desa yang terdiri atas Kepala Desa dan unsur pembantu kepala desa. Selain itu, demi terlaksananya proses pemerintahan desa yang baik maka pemerintah desa akan dibantu dan diawasi juga oleh Badan Permusyawaratan Desa (Tabrani Rusyam,2018:5-6). Namun, Penyelenggaraan pemerintahan yang kuat hanya dapat terwujud jika partisipasi masyarakat lokal desa sangat tinggi dalam pembangunan desa. Perencanaan pembangunan desa diselenggarakan dengan mengikut sertakan masyarakat desa melalui musyawarah perencanaan pembangunan desa. Berkaitan dengan hal itu, dalam Pasal 114 Ayat (1) PP No.43 Tahun 2014 Tentang Aturan Pelaksanaan UU Desa, menyebutkan bahwa perencanaan pembangunan desa disusun berdasarkan hasil kesepakatan dalam musyawarah desa, kemudian dalam Pasal 116 Ayat (1) disebutkan pula bahwa dalam menyusun RPJMDes dan RKP Desa, pemerintah desa wajib menyelenggarakan musyawarah perencanaan pembangunan 
desa secara partisipatif, artinya pemerintah desa tentu harus melibatkan seluruh elemen yang ada di desa

Oleh karena itu, Pembangunan desa pada hakikatnya dilaksanakan dengan semangat gotong royong serta memanfaatkan kearifan lokal dan sumber daya alam desa. Selain itu, dalam Penyusunan Rencana pembangunan desa serta penyusunan APB Desa dilakukan dengan melibatkan partisipasi masyarakat dan Informasi tentang keuangan desa secara transparan dapat diperoleh oleh masyarakat (Pamungkas, 2019).

\section{B. Analisis Kinerja Pemerintahan Desa Sekeladi Dalam Penyusunan RKP Desa}

Pembangunan desa adalah pembangunan manusia seutuhnya dan seluruh masyarakat Indonesia. Selain itu, pembangunan desa bertujuan untuk meningkatkan kesejahteraan masyarakat desa dan kualitas hidup manusia serta penanggulangan kemiskinan melalui penyediaan pemenuhan kebutuhan dasar, pembangunan sarana dan prasarana, pengembangan potensi ekonomi local, serta pemanfaatan sumber daya alam dan lingkungan secara berkelanjutan. (M. Muiz Raharjo,2020:59). Sebagaimana dijelaskan dalam Permendagri Nomor 114 tahun 2014 bahwa pembangunan desa dilaksanakan oleh pemerintah desa dengan melibatkan seluruh masyarakatnya dengan semangat gotong royong. Adapun hasil kinerja pemerintah desa dapat dilihat dari beberapa indikator kinerja yakni: efisiensi kinerja, efektifitas, keadilan serta daya tanggap aparat pemerintahan desa (Kumoroto, 2005: 78).

Maksimal atau tidaknya kinerja pemerintahan desa dalam melaksanakan pembangunan desa akan mempengaruhi kemajuan desa, dengan demikian pemerintahan desa memiliki kewajiban melaksanakan pembangunan di desa secara optimal, baik lewat kinerja aparat pemerintahan maupun dalam proses penyusunan rencana pembagunan. Terkait dengan hal itu, Pemerintahan Desa Sekeladi, merupakan desa yang beberapa tahun belakangan memiliki keawjiban melaksanakan pembangunan desa sesuai dengan ketentuan yang terdapat dalam UU Desa. Namun, dalam penyusunan RKP Desa Pemerintahan Desa dianggap belum serius, tidak melakukan kajian yang mendalam tentang arah pembangunan desa, bahkan terkesan mengabaikan aspirasi masyarakat yang ada. Oleh karena itu, maka peneliti akan mencoba menganalisis permasalahan tersebut melalui studi Pustaka dan jawabanjawaban hasil wawancara dengan informan terkait kinerja pemerintahan desa dalam penyusunan RKP Desa di Desa Sekeladi dengan beberapa indikator dibawah ini. 


\section{Efektivitas dan Efisiensi Kinerja Pemerintahan Desa}

Pada hakikatnya efisiensi menyangkut tentang keberhasilan organisasi pemerintah desa untuk memanfaatkan faktor-faktor produksi serta pertimbangan yang berasal dari rasionalitas ekonomis. Berdasarkan hasil wawancara dengan Kepala Desa Sekeladi Bapak Jhoni Efendi mengatakan bahwa "Selama berlakunya program ADD dan pembangunan desa, pemerintah desa terfokus pada prmbangunan jalan dan pembuatan jembatan (gorong-gorong). Disamping itu, berdasarkan hasil wawancara Peneliti dengan ketua BPD Desa Sekeladi mengatakan "bahwa BPD tidak pernah ikut membahas masalah rencana pembangunan desa, dan hanya mengetahui hasilnya saja”. Selanjutnya, Peneliti juga melakukan wawancara terkait hal itu dengan tokoh masyarakat yaitu Bapak Syafri dan Bapak Rozali, mengatakan bahwa "Saya masih kurang paham tentang kemana arah pembangunan Desa Sekeladi ini, sebagai contoh pembuatan jalan kearah kebun karet masyarakat banyak yang mangkrak dan tidak diselesaikan dengan baik pengerjaannya”.

Oleh karena itu, berdasarkan hasil wawancara tersebut Peneliti menyimpulkan bahwa belum efisien nya kinerja pemerintahan desa sekeladi, karena kurangnya kerja sama yang baik antar lembaga desa serta monotonnya arah pembangunan desa sehingga kurang efisien dalam mencapai tujuan pembangunan desa.

\section{Keadilan dan Daya Tanggap Pemerintahan Desa}

Pada hakikatnya keadilan akan selalu mempertanyakan arah distribusi dan alokasi layanan yang diselenggarakan oleh organisasi pelayanan public apakah sesuai dengan prinsip-prinsip keadilan. Selanjutnya, Daya Tanggap, yaitu mengindikasikan tentang sejauh mana organisasi atau pelayanan publik dalam menanggapi kebutuhan dasar masyarakat.

Berdasarkan hasil wawancara Peneliti dengan beberapa tokoh masyarakat desa Sekeladi yaitu Bapak Alfajri mengatakan “pembangunan Desa Sekeladi kurang tepat sasaran dan terkesan hanya kepentingan kelompok, seperti pembangunan jalan dan jembatan yang pada umumnya hanya dibangun menuju arah kebun orang-orang yang berkuasa di desa saja”. Selain itu, Bapak Inasri Abbas, S.Pd,I juga mengatakan "menurut saya pemerintahan desa Sekeladi masih kurang memahami dan menerima aspirasi masyarakat, contohnya saja selama ini sudah bertahun-tahun pemuda meminta fasilitas olahraga yang layak, namun sampai hari ini belum pernah ditanggapi”. 
Selanjutnya, Bapak Alfajri juga mengatakan bahwa "Pemerintah desa Sekeladi tidak paham kata adil dalam proses pembangunan infrastruktur, seharusnya adil yang dimaksud yaitu pembangunan desa seharusnya melihat kepentingan masyarakat desa, populasi masyarakat desa serta luas wilayah masyarakat desa”. Oleh karena itu, berdasarkan hasil analisis terhadap wawancara tersebut diatas serta juga diperkuat dengan hasil observasi dilapangan, Peneliti menilai bahwa memang Pemerintaha Desa Sekeladi masih kurang tanggap terhadap kepentingan masyarakat Desa Sekeladi.

\section{Faktor-Faktor Yang Mempengaruhi Kinerja Pemerintahan Desa Sekeladi Dalam Penyusunan RKP Desa}

Berdasarkan hasil analisis terhadap jawaban para informan saat proses wawancara, serta kesimpulan dari serangkaian observasi yang Penulis lakukan di lapangan terkait penyusunan RKP Desa di Desa Sekeladi. Oleh karena itu, Penulis menyimpulkan beberapa hal yang menjadi faktor kurang optimalnya kinerja Pemerintahan Desa Sekeladi dalam penyusunan RKP Desa, yaitu sebagai berikut:

a. Kurangnya koordinasi dan kerjasama antar lembaga Pemerintahan Desa Sekeladi dalam penyusunan RKP Desa.

b. Kurang maksimalnya kinerja dari tim penyusun RKP Desa dalam memahami dan mengkaji arah pembangunan Desa Sekeladi, sehingga terkesan hanya mementingkan kepentingan kelompok saja.

c. Kurang tanggapnya Pemerintahan Desa Sekeladi dalam menyerap aspirasi aspirasi dan keinginan masyarakat Desa Sekeladi.

d. Masih kurangnya kesadaran dan partisipatif dari masyarakat dalam mendukung program RKP Desa yang disahkan oleh Pemerintah Desa.

\section{SIMPULAN}

Berdasarkan hasil penelitian yang telah dilaksanakan, serta telah dilengkapi dengan serangkaian proses analisis yang telah dijelaskan sebelumya, maka Peneliti berkesimpulan bahwa kinerja dari Pemerintahan Desa Sekeladi dalam penyusunan RKP Desa selama ini belum terlaksana secara baik. Hal itu terjadi karena masih kurangnya kerja sama antar organisasi pemerintahan desa.

Selain itu, faktor lain yang menyebabkan kurang maksimalnya kinerja Pemerintahan Desa Sekeladi dalam penyusunan RKP Desa pada tahun 2019-2020, adalah kurangnya daya tanggap pemerintahan desa dalam menyerap dan menerima 
aspirasi masyarakat desa. Hal itu dibuktikan dari pembangunan infrastruktur jalan, pembuatan gorong-gorong hanya dilakukan di daerah perkebunan milik warga dan kelompok tertentu saja, sehingga mengabaikan hal yang prioritas serta aspirasi dan keinginan masyarakat Desa Sekeladi yang lainnya. Pembangunan desa sepatutnya mampu menggerakkan perekonomian di desa dan menciptakan lapangan pekerjaan baru. Pembangunan di desa juga seharusnya tidak mengakomodir kepentingan satu kelompok saja sehingga kelompok masyarakat lain menjadi terpinggirkan.

\section{DAFTAR PUSTAKA}

Adon Nasrullah Jamaludin, 2015, Sosiologi Pedesaan, CV. PUSTAKA SETIA: Bandung.

Al Sukri, S., Prihastuti, A. H., \& Julina, J. (2020). Pelatihan Laporan Keuangan Bagi Pengurus BUM Desa Sekapur Sirih. To Maega: Jurnal Pengabdian Masyarakat, 3(2), 130-141.

Anwar Prabu Mangkunegara, 2007, Evaluasi Kinerja Sumber Daya Manusia, PT. Refika Aditama, Bandung.

Arenawati, 2014, Administrasi Pemerintahan Daerah, Sejarah, konsep dan penatalaksanaan di Indonesia, Graha Ilmu: Yogjakarta.

Budiono, P. (2015). Implementasi Kebijakan Badan Usaha Milik Desa (Bumdes) Di Bojonegoro (Studi di Desa Ngringinrejo Kecamatan Kalitidu Dan Desa Kedungprimpen Kecamatan Kanor). Jurnal Politik Muda, 4(1), 116-125.

Didik G. Suharto, 2016, Membangun Kemandirian Desa, Pustaka Pelajar: Yogyakarta. Harbani Pasolong, 2010, Teori Administrasi Publik, Alfabeta: Bandung.

Huraerah, Abu. 2008, Pengorganisasian, Pengembangan Masyarakat Model dan Strategi Pembangunan Berbasis Masyarakat, Humaniora: Bandung.

Ilosa, A., Al Sukri, S., \& Rudiadi, R. (2021). Asas Transparansi Dalam Proses Pengangkatan Perangkat Nagari. Jurnal Ilmiah Muqoddimah: Jurnal Ilmu Sosial, Politik dan Hummanioramaniora, 5(1), 71-83.

J. Kaloh, 2007, Mencari Bentuk Otonomi Daerah, Rineka Cipta: Jakarta

Kamus Besar Bahasa Indonesia, KBBI.

Muiz Raharjo, 2020, Adminisrasi Pemerintahan Desa Di Indonesia, Pustaka Pelajar: Yogyakarta. 
Ni'matul Huda, 2015, Hukum Pemerintahan Desa, Setara Press: Malang, Jatim.

Pamungkas, B. A. (2019). Pelaksanaan Otonomi Desa Pasca Undang-Undang Nomor 6 Tahun 2014 Tentang Desa. Jurnal USM Law Review, 2(2), 210-229.

Peraturan Kepenghuluan Sekeladi Tentang APBKep Sekeladi 2019.

Peraturan Pemerintah Nomor 43 Tahun 2014 Tentang Aturan Pelaksanaan Undangundang Desa.

Permendagri Nomor 114 Tahun 2014 Tentang Pedoman Pembagunan Desa.

Romli, O., \& Nurlia, E. (2017). Lemahnya Badan Permusyawaratan Desa (BPD) dalam Melaksanakan Fungsi Pemerintahan Desa (Studi Desa Tegalwangi Kecamatan Menes Kabupaten Pandeglang). CosmoGov: Jurnal Ilmu Pemerintahan, 3(1), 36-54.

Soimin, 2019, Pembangunan Berbasis Desa, Cetakan Pertama (Intrans Publishing), Malang, Jatim.

Tabrani Rusyam, 2018, Membangun Efektifitas Kinerja Kepala Desa, Cetakan Pertama (PT. Paragonatama Jaya), Jakarta.

Undang-Undang Nomor 6 Tahun 2014 Tentang Desa

Undang-undang Nomor 5 Tahun 1979 tentang Pemerintahan Desa

Wahjudin, dalam Nurman, 2015, Strategi Pembangunan Daerah, Cetakan ke-1 (PT. RajaGrafindo Persada, Jakarta).

Wahyudi Kumoroto, 2005, Anggaran Berbasis Kinerja, Konsep dan Aplikasinya. Magister Administrasi Publik UGM: Yogyakarta.

Yohanes, M. (2018). Pelaksanaan Rekrutmen Perangkat Desa di Kabupaten Kulon Progo Penelitian Deskriptif Kualitatif di Desa Gotakan, Kecamatan Panjatan, Kabupaten Kulon Progo, Daerah Istimewa Yogyakarta. 